\title{
Nadine Gordimer's Strangely Uncanny Realistic Stories: The Chaos and the Mystery of It All
}

\section{Liliane Louvel}

\section{(2) OpenEdition}

1 Journals

Electronic version

URL: https://journals.openedition.org/ces/424

DOI: $10.4000 /$ ces. 424

ISSN: 2534-6695

Publisher

SEPC (Société d'études des pays du Commonwealth)

\section{Printed version}

Date of publication: 10 June 2019

Number of pages: $39-50$

ISSN: 2270-0633

\section{Electronic reference}

Liliane Louvel, "Nadine Gordimer's Strangely Uncanny Realistic Stories: The Chaos and the Mystery of It All", Commonwealth Essays and Studies [Online], 41.2 | 2019, Online since 05 November 2019,

connection on 08 December 2022. URL: http://journals.openedition.org/ces/424 ; DOI: https://doi.org/ $10.4000 /$ ces. 424

\section{(c) (i) (9)}

Creative Commons - Attribution-NonCommercial-NoDerivatives 4.0 International - CC BY-NC-ND 4.0 https://creativecommons.org/licenses/by-nc-nd/4.0/ 


\section{Nadine Gordimer's Strangely Uncanny Realistic Stories: The Chaos and the Mystery of It All}

This paper purports to study and develop an aspect of Gordimer's fiction which has often been overlooked. Uncanny elements may be identified all along her career constituting a kind of return of the repressed. Insects, animals, landscapes, unidentified threats and fears loom large in the background and constitute a menace for the white population most of the time. The black population is confronted with even more direct brutal problems. Thus in an indirect way, an allegorical one in the sense of the etymological "speaking other," "the situation" under the state of Apartheid is addressed and denounced. Gordimer's so-called realistic short stories turn out to contain eerie uncanny features. The geography and the history of this African country are called upon to testify to a violent past inscribed on the landscape by mapmakers.

Nadine Gordimer has often been hailed as a realist writer, even a social realist one, but reading her novels and especially her short stories, one cannot help but be struck by the presence, as if looming in the background, of the uncanny. Persistent, unusual, even unheimlich ${ }^{1}$ situations or events reveal another side of the writer's art showing she could use all the tools a writer has at her fingertips to reach her aim. Gordimer always insisted that she started writing as a young fifteen-year old in a mining town and that she was chosen by the situation, and did not choose it herself. She happened to be a writer writing in South Africa but first and foremost she was a writer. In her introduction to her Selected Stories published in 1975, she insists on her own take on what a commitment is and simultaneously addresses the (im)possibility of defining the elusive form of the short story compared to that of the novel:

What I am [...] saying, then, is that in a certain sense a writer is "selected" by his subject - his subject being the consciousness of his own era. How he deals with this is, to me, the fundament of commitment, although "commitment" is usually understood as the reverse process: a writer's selection of a subject in conformity with the rationalization of his own ideological and/or political beliefs.

My time and place have been twentieth-century Africa. Emerging from it, immersed in it, the first form in which I wrote was the short story. [...]

[A] short story is a concept that the writer can "hold," fully realized, in his imagination, at one time. $[. .$.$] A short story occurs, in the imaginative sense. To write one is to express$ from a situation in the exterior or interior world the life-giving drop - sweat, tear, semen, saliva - that will spread an intensity on the page; burn a hole in it. (Selected Stories 14-5, emphasis in original)

The very sensual and concrete way she addresses the question of creation alluding to sweat, tears, semen and saliva, together with the role of imagination, exemplify Gordimer's own way of dealing with "a situation" as she calls it, whether happening in the interior or the exterior world. I shall concentrate on this surprising - for a writer deemed realist and a committed one at that - side of her art, the presence of what she calls "fantasy" verging on the uncanny in her short stories, together with the use of the visual

1. I am using "unheimlich" following Sigmund Freud's "das Unheimliche" (the uncanny), and as applied to the postcolonial context by Homi Bhabha in The Location of Culture. 
and the recurring reference to the unknown impressive/oppressive mysterious presence of the all-enfolding "dark continent" and its inhabitants claiming their due even while assuming the looming shape of a frightening presence lurking on thresholds. Although based on a grim reality, sometimes her stories verge on the genre of the fable or of the cruel fairy tale. A very clear example of this is the so-called Christmas story she wrote for Salmagundi, "Once Upon a Time," which takes the canonical form of the fairy tale but ends up as a very cruel one with the death of the little boy maimed by the many defense contraptions built by his parents, egged on by "the old witch" his grandmother, to protect them against the outside invaders.

\section{"The Flash of Fireflies": a visual take on the short story}

For Gordimer, the short story is the ideal form for writing about a moment producing a close-up effect on a situation. It is close to poetry and can be read "at one sitting" (Poe) which, in a country for a long time living in "a state of siege" - from the sixties till the nineties - was an asset: it was easier to concentrate on a short text rather than on the longer form of the novel. ${ }^{2}$

In her essay "The Flash of Fireflies," Gordimer is once again led to compare the forms of the novel and of the short story. In terms of their relationship she comments on the short story's ability to

capture the ultimate reality at a time when $[. .$.$] we are drawing nearer to the mystery of life$ or are losing ourselves in a bellowing wilderness of mirrors, as the nature of that reality becomes more fully understood or more bewilderingly concealed by the discoveries of science and the proliferation of communication media outside the printed word. (179)

The fact that she wrote this in 1968 shows she had an inkling of what would rule our world some 50 years later: the importance of communication media to enhance, transpose or conceal reality in a very different way from the printed word. At a time when a book can be read like an image from a digital screen this can sound anticipatory indeed. Of note too is her use of a potent synesthesia mixing the visual and the aural and resorting to "a bellowing hall of mirrors" to illustrate her impression of being at a loss. We shall see that thinking in images is one of the characteristics of Gordimer's aesthetics.

She insists on the paradox of the nature of the reality captured by fiction when it may be "more fully understood" or "bewilderingly concealed" by scientific advances and communication media. Therefore, she is led to examine the complex relation of fiction to fantasy and to what she calls "the ultimate reality." She then resorts to another very visual idiom to convey her meaning, showing how she tends to think in images. Fantasy, she claims, is no more than "a shift in angle" in relation to reality and the rational. "Flashes of fearful insights alternate" with lulled states of indifference:

Writers are becoming more and more aware of the waviness of the line that separates fantasy from the so-called rational in human perception. It is recognized that fantasy is no more than a shift in angle; to put it another way, the rational is simply another, the most obvious, kind of fantasy. Writers turn to the less obvious fantasy as a wider lens on ultimate reality. But this fantasy is something that changes, merges, emerges, disappears as a pattern does

2. Black writers in South Africa also chose the theatrical form for this reason. Thus they were able to address their audience directly before being chased away by the police, in a maximum of an hour and a half, the time necessary to read a short story too. Poetry was also a favourite means of literary expression for black writers then. They often could not spare days and months for writing novels. When they were not exiled like Ez'kia Mphalehle, Gordimer felt close to them. 
viewed through the bottom of a glass. It is true for the moment when one looks down through the glass; but the same vision does not transform everything one sees, consistently throughout one's whole consciousness. Fantasy in the hands of short-story writers is so much more successful than when in the hands of novelists because it is necessary for it to hold good only for the brief illumination of the situation it dominates. [...] [T] he short story is a fragmented and restless form, a matter of hit or miss, and it is perhaps for this reason that it suits modern consciousness which seems best expressed as flashes of fearful insight alternating with near-hypnotic states of indifference. ("Fireflies" 180-1, my emphases)

Her comparison is close to the fragile kaleidoscopic view one may ascribe to her writing and the way she renders her multicoloured ever-changing view of her society, as so many bits of geometric glass "viewed through the bottom of a glass." The result is a pattern and an image close to those produced by fantasy when reality (that of bits of coloured glass and mirrors) is distorted under a wider lens or a microscope.

In the same essay, she develops her conception of the short story as a brief illuminating moment she calls, returning to one of her favourite images using insects, "the flash of fireflies." She evokes "the quality of human life, where contact is more like the flash of fireflies, in and out, now here, now there, in darkness" and explains that "[s]hort story writers see by the light of the flash; theirs is the art of the only thing one can be sure of - the present moment" (180, emphasis added).

The short story therefore gives us quick glimpses of particular moments, it triggers a sudden vision of a fugitive reality temporarily anchored in the present of the event, and no more. The "flash of fireflies" as aesthetic principle, and the use of punctuation as we shall see later on, are also akin to one of Woolf's striking short stories written during the Blitz, "The Searchlight" (269-72). In this story, the recurring use of three dots marking the text mimics the rotating action of the searchlight as seen from a tower by the characters.

Gordimer's seminal image, that of the flash of fireflies, expressing her aesthetic and ethical approach, reappears with variation in a later short story. In "Something Out There," published in 1984, the white terrorist is stopped at a barrier while a train passes by. He finds himself alongside the estate agent who lets him the dilapidated farmhouse, and his wife, in their car. After a moment of anxiety, he feels free to give a social sign of good will. The description of the light thrown onto the veld by the lit-up train windows projecting flashes on the veld, which the narrator compares to a camera lens, echoes Gordimer's essay:

On one of [Charles's] return trips, he drew up at the level crossing and found himself beside Naas Klopper and Mrs Naas in the Mercedes. A train shuttered past like a camera gone beserk, lens opening and closing, with each flying segment of rolling stock, on flashes of the veld behind it. The optical explosion invigorated Charles. He waved and grinned at the estate agent and his wife. (139)

This gives the reader a key to her short story writing within the core of the story itself, conceived of as a succession of luminous visions and significant moments caught in a glimpse.

This striking image will allow me to argue that one of the means she resorts to so as to convey the often elusive "ultimate reality" is the constant but discreet presence of the visual in her work. It may directly figure like photography (in "Jump" and in "Amnesty"), or indirectly, when the visual is a means of translating reality into vision in a recurring description ("Livingstone's Companions"), or as a potent symbolical image 
verging on the allegorical, the gruesome and the macabre ("Six Feet of the Country," The Conservationist) as we shall see.

\section{Making use of "significant detail": Looking through a microscope}

One of the constant marvels of Gordimer's texts and a salient stylistic trait is the way she manages to bring to the European reader's eyes the very presence of such a far-off country, its landscape and its people by describing minutiae. She gives us an insect-like view of plants, gardens, clothes, houses, and of course people, focussing for instance on their calloused feet when black people arrive barefoot. In "Spoils," people marvel at the mound of guts which spill out of the zebra and at the frenzied insects' activity going on there. The writing microscope is doing its minute studying work. Note once more the reference to insects and scarabs:

What's going on here is a visible transformation of an inert mass. It is literally being carried away by distinctly different species of beetles who know how to live by decay, the waste of the digestive tract. The scarabs with their armoured heads burrow right into the base of the mound, and come out backwards, rolling their ball of dung between their strong, toned legs. The tunnels they have mined collapse and spread the mound more thinly on its periphery; smaller beetles are flying in steadily to settle there, where their lighter equipment can function. (177)

Of course, focussing on detail is part of Gordimer's visual way of writing and the hallucinatory way with which she tries to capture "the ultimate reality," verging on the unheimlich at times, as if magnified by a microscope. This is a trait she shared with Woolf too who was described as dissecting people like insects, providing her readers with an entomologist's point of view. In "The Lady in the Looking Glass" (Shorter Fiction 221-5), for instance, the lady is submitted to close analysis as if she were being etched, divested of her superficial being all at once.

Defining once the import of "the significant detail" and the necessity of what she called "the fresh eye" Gordimer once argued:

It's significant detail that brings any imaginative work alive, whatever the medium. If you can't see things freshly, if you can't build up through significant detail, then I think you fall into cliché, not only in the use of words and phrases, but even in form. That fresh eye is the most valuable thing in the world for any writer. [...] In The Conservationist, the landscape is the most important character. So therefore, it had to be allowed to speak and the land could only speak and come alive for the reader through my finding its significant details. (Conversation 13)

The visuality of the scenes in "Spoils" for instance is so vividly intense at times that one has the feeling of actually seeing the cubs tearing at the zebra's flesh, or black people's cracked skin and dirty feet or the thick fabric of the blanket they wear on the veld. In the same way, when the younger generation try to give up the older ways of dressing, as in "Amnesty," the narrator provides an abundance of detail showing how the young wife of the political prisoner, on her way, she hopes, to Robben Island to visit him with his parents, is dressed to look modern:

I wasn't wearing, any more, the old beret pulled down over my head that farm girls wear. I had bought relaxer cream from the man who comes round the farms selling things out of a box on his bicycle, and my hair was combed up thick under a flowered scarf that didn't cover the gold-coloured rings in my ear. His mother had a blanket tied round her waist over her dress, a farm woman, but I looked just as good as any of the other girls there. (250) 
In this story, we are given a vision of life on a farm in the veld, the man going round "selling things" together with details of colour, shape, fabric, as if people were put under a microscope.

\section{Fictional ethics: "Living in the interregnum"3}

In this in-between situation of the "interregnum," the uncanny seems to be a way of sharing one's sense of the bizarre as well as acting in accordance with one's ethics: "As a writer, I think that my first duty is integrity as an artist. I have a superstitious notion that if I lie, my characters will be damaged, somehow; their verity will be destroyed" (Conversation 5). Gordimer's stories sometimes verge on the uncanny. Although anchored in a then contemporary time and place (although they may not be accurately pinned down), her stories seem to be suspended in a floating in-between allegorical world.

In quite a number of Gordimer's short stories the reader can identify images signifying the return of the repressed pointing to strong harm and shady dealings. Regarding land spoliation, a potent image keeps haunting the short stories as well as some of the novels: I will call this the "resurgence of corpses." Gordimer once answered a question about Alan Paton's Cry the Beloved Country, by insisting on the absence of rights to the land of white people, claiming the rightful inheritors of it were black people, insisting on this through paronomasia (there/theirs):

I think that whites are always having to assert their claim to the land because it's based, as Mehring's mistress points out, on a piece of paper - a deed of sale. And what is a deed of sale when people have first of all taken a country by conquest? Tenure is a very interesting concept, morally speaking. When you come to think of it, what is tenure? What is "legal" tenure? Blacks take the land for granted, it's simply there. It's theirs, although they've been conquered; they were always there. They don't have the necessity to say "Well I love this land because it's beautiful, because it's this, that, and the other." ("Conversation" 6)

The returning corpses coming to claim their land as theirs in order to be decently buried already appeared in an early story of Gordimer's dating back to 1953, "Six Feet of the Country."

The story, or rather novella, "Something Out There," also illustrates the theme of the return of the repressed and the uncanny haunting of white people's suburbs and conscience. The title itself pinpoints the undetermined although frighteningly grotesque shape which has been spied by several people without their being able to identify it: a black man? An ape? A baboon? Nevertheless, such crimes as stealing fruit, venison and all kinds of available food, rummaging in dustbins, climbing trees, killing pets, frightening servants, are committed and give rise to a chorus of voices in the suburbs and the newspapers. From well-off and plush suburbs, the haunting moves to not-so-rich ones and then even to white working-class suburbs. The police in the infamous John Vorster square (a place where torture was used to extort confessions) are powerless. This story strand develops at the same time as a second one: two white people and two black people are secretly hiding in a deserted farmhouse "out there," preparing to sabotage the local power station, an endeavour they manage to carry out with success. So the town is under two different sets of threats, and when the sabotage deprives

3. "The old is dying and the new cannot be born; in this interregnum there arises a great diversity of morbid symptoms." Antonio Gramcsi, Prison Notebooks, quoted as an epigraph by Nadine Gordimer to her July's People (1981). 
them of power, the looming animal threat recedes into the background and... from the newspapers. Still, at the end, the beast is recognized for what it is, and loses its haunting dimension. It is cornered and killed.

At the end of the story, the narrator weaves together the various historical strands of the making of the country and of its inhabitants, be they natives or emigrants. Their ascendancy goes back to a common ancestor, as Dr Grahame Fraser-Smith remembers "looking back in fancy into the eyes of hominid evolution on a golf course" "Something Out There" 203). The various characters in the story, as well as the ape and the copy of a rare statue similar to Indian ones, are all fused, as well as the land and its deep mines where two of the terrorists hide, preparing the final stage of the attack. But once again, the true owners of the mine are eventually restored to their rights by the all-knowing narrator:

The mine-working where Eddie and Vusi hid, that Charles identified as belonging to the turn of the $19^{\text {th }}$ century, is in fact far, far older. It goes back further than anything in conventional or alternative history, or even oral tradition, back to the human presences who people anthropology and archeology, to the hands that shaped the objects or fired the charcoal which may be subjected to carbon tests. No one knows that with the brief occupation of Vusi and Eddie, and the terrible tools that were all they had to work with, a circle was closed because before the gold-rush prospectors of the 1890s, centuries before time was measured, here, in such units, there was an ancient mine-working out there, and metals precious to men were discovered, dug and smelted, for themselves, by black men.

(“Something Out There” 203)

The "hominid ascendancy" who came back to haunt the suburbs were claiming what was theirs by right of first occupation, and the mines of old provided a cache and a cradle for their descendants trying to claim their inheritance.

It should be noted that Gordimer here uses animals to represent her aim in a symbolical way: the baboon is a case in point, but we also find insects as in the "flash of fireflies" or in another early story, "The Termitary," in which termites undermine the white family house, threatening to topple it. They then have to call in the competent men who bring about total chaos in the house. In "Amnesty," the concluding story in Jump, the black woman is awaiting her militant husband watching the clouds in the shape of a rat eating away at the clouds. She is waiting for her land and for the time to call it hers, her home.

I'm watching the rat, it's losing itself, its shape eating the sky, and I'm waiting. Waiting for him to come back.

Waiting.

I'm waiting to come back home. (257)

The gruesome presence of death and of the return of the dead set in the overwhelming Southern African landscape also lies at the core of stories clearly set "in the heart of the country" (Coetzee). Strange visions arise in a landscape to which the white man or woman are completely alien. The uncanny imbues the quest journalist Carl Church is sent on when, on the commemoration of the hundredth anniversary of Livingstone's death, he is sent to the interior to find the graves of "Livingstone's Companions." 


\title{
In the Heart of the (Dark) Country: of Livingstone, Friday and others
}

\begin{abstract}
J.M. Coetzee's In the Heart of the Country is set on a farm deep in the veld. The title of this sombre novel dealing with racial prejudice and the ever-recurring theme of love between a black man and a white woman, and the Hegelian master/slave relationship, echoes Conrad's own Heart of Darkness as well as Henry Morton Stanley's Through the Dark Continent published in 1878. Gordimer herself chose an extract from the novel by Conrad as an epigraph to one of her early pieces (1960-1) published in The Essential Gesture. "The Congo River" explores the fantastic powerful myth-laden snake-like river which flows right into the heart of Africa. It is the same river Livingstone explored when he was attempting to find the source of the Nile.

... A place of darkness. But there was in it one river especially, a mighty big river, that you could see on the map, resembling an immense snake uncoiled, with its head in the sea, its body at rest curving afar over a vast country, and its tail lost in the depths of the land. (Heart of Darkness, quoted in Essential Gesture 157)
\end{abstract}

In this extraordinary travelogue, in which Gordimer renders the beauty of the river and the sense of awe she felt during her journey, she notes:

From Stanley-Pool the Congo opens a way more than a thousand miles, without a manmade lock or a natural obstacle, through the centre of Africa. It leads to what Joseph Conrad called the heart of darkness; the least-known, most subjectively described depths of the continent where men have always feared to meet the dark places of their own souls. (Essential Gesture 163)

And "the dark places of their own souls" are exactly what Gordimer also set out to probe and sound in her writing, as one sounds the depths of a river to find dead corpses. Her account of the voyage into the interior casts an interesting light on some of her later stories such as "Livingstone's Companions" and "Friday's Footprint."

In these stories, the uncanny mingles with the fascinating and fear-inducing interior of Africa. Its "darkness," expressing the sense of the unknown, of mystery mingled with fear when one is confronted with dark foliage, huge trees, apparently uninhabited shores and tumultuous cataracts and falls, is duly fantasized and experienced, providing visions of beauty and dread. In the stories the overall presence of water, be it the powerful river or a beautiful far-reaching lake, plays a great part. In "Livingstone's Companions" and "Friday's Footprint," two widowed women are left in charge of a hotel located in the middle of nowhere. People come for a rest there after a safari or because of their administrative functions like the permanent guests in "Friday's Footprint": "The veterinary officer, the meteorological officer and the postmaster" (156).

The "Friday" of the story is Mrs. Cunningham, the hotel owner. Tourists

emerge from their jeeps feeling unreal. The sight of Mrs. Cunningham, in her flowered print dress with a brooch on her big bosom, and her big, bright-skinned face looking clerically dazed beneath her thick permanent, was the known world, to them; Friday's footprint in the sand. (146)

Just as Friday's footprints left on the beach provide Crusoe with the signs of a human presence, Mrs. Cunningham provides guests with a homely recognizable presence when they reach her hotel in Central Africa, by the river. But although Mrs. Cunningham is a kind of reassuring mother figure, she herself suffers from some potent recurring nightmarish visions: 
Rita Cunningham did not always see nothing when she turned to look at the water. Sometimes (what times? She struggled to get herself to name - oh, times; when she had slept badly, or when - things - were not right) she saw the boat coming across the flooded river. She looked at the wide, shimmering, sluggish water where the waterlilies floated shining in the sun and she began to see, always at the same point, approaching the middle of the river from the other bank, the boat moving slowly under its heavy load. It was their biggest boat; it was carrying eight sewing machines and a black-japanned iron double bedstead as well as the usual stores, and Arthur and three store-boys were sitting on top of the cargo. As the boat reached the middle of the river, it turned over, men and cargo toppled, and the iron bed came down heavily on top of their flailing arms, their arms stuck through the bars as the bed sank, taking them down beneath it. That was all. There was a dazzle of sun on the water, where they had been; the waterlilies were thickest there.

She had not been there when it happened. (147)

Undoubtedly this is a fantasized vision testifying to the repetition of a traumatic event she experiences again and again by proxy since she did not witness it. She will wonder who described for her the ugly details about the arms caught up in the bars of the bedstead her husband, Arthur, had insisted on piling up on top of the overladen boat. This vision recurs four times in various forms in the story. The last one, when things are not going too well with her second husband, Johnny, her first husband's step-brother, is poignant.

Arthur! She called in a clenched, whimpering whisper, Arthur! Grinding his name between her teeth, and she turned desperately to the water, to the middle of the river where the lilies were. She tried with all her being to conjure up once again out of the water something; the ghost of comfort, of support. But that boat, silent and unbidden, that she had so often seen before, would not come again. (166)

She recalls the former image of the water and the lilies so quick to cover over the traces of the wreckage. As in the novella, "Something Out There," she is trying to conjure up "something," which expresses the strength of the unnamable presence invading one's conscience and unconscious. But this time there is nothing.

Still further into the heart of the country, near the Congo, as in Stanley's search for Livingstone in 1871, journalist Carl Church, sent by his newspaper, is sent on a quest too. His name also evokes Livingstone's missionary calling. C. Church has to find the graves of Livingstone's companions dead and lost in the heart of Africa a century before. Reading Livingstone's Last Journals telling of his companions' deaths - pages of which are copied in the story, italicized - Carl first starts off reluctantly and gets lost in the bush. He eventually finds his way to a hotel, the lady-owner of which he met on their plane to Moambe. She claims the graves are on her property but he cannot find them. Instead, he finds "an odd ruin: a solid complex of buildings, apparently not in bad repair, [which] had been pulled down [...]. The bush was all around as far as the Congo, as far as the latitude where the forests began" (364-5).

But little by little he is enticed by the stunning beauty of the lake and the fishing he hugely enjoys. His deep-water fishing is described in quasi-religious terms, mingling life, death and magic:

Then he saw the fish, deep down, twenty feet maybe, a yellowish nonchalant shape which seemed to pasture in a small forest of short dead reeds. [...] The miracle happened again. The nonchalant shape became a frenzied spot of light, reflecting the rays of the sun in a series of flashes through the pale blue water as it swivelled in agony round the spear. It was - this moment - the only miracle Church knew [...]. (367-8) 
Mesmerized by the light and the allure of the lake and its hidden life, Carl Church stays longer than expected without finding the graves. On his way back to the airport, he unexpectedly finds them, together with a bit of history:

Suddenly he saw the path, the path he had missed the other day, to the graves of Livingstone's companions. [...] [A]nd then there, where the slope of the hill came up short against a steep rise, the gravestones stood with their backs to rock. The five neat headstones of the monuments commission were surmounted each by an iron cross on a circle. The names, and the dates of birth and death - the deaths all in the last quarter of the nineteenth century - were engraved on the granite. (376-7)

There is one extra gravestone, that of the hotel owner's husband who died in 1957: one more ghost of a hotel founder, still present on this spot of bush and memories, like Mrs. Cunningham's dead husband. Whilst the lake again is granted pride of place, we are given to read this extraordinary, beautiful passage:

They all looked back, these dead companions, to the lake, the lake that Carl Church (turning to face as they did, now) had had silent behind him all the way up; that lake that, from here, was seen to stretch much farther than one could tell, down there on the shore or at the hotel: stretching still - even from here - as far as one could see, flat and shining, a long way up Africa. (377)

I have tried to show the ways in which Gordimer suggests the upsurge of the uncanny disrupting the familiar, how, as in another story, "An Intruder," the unexplained wreckage of a young couple's house turns out to have been perpetrated by the enemy within. Under the influence of alcohol, the husband nightly wreaks havoc on their home and wakes up unaware of his actions. Destructive and violent, he is in a borderline state. Once more the insect simile is called upon ("To her evil had come out of the walls, as the black beetles did in the kitchen") till she understands it all:

'No, I told you. I went into the living room to get a bottle of lime juice, I went into all the rooms,' she repeated in her soft, slow, reasonable voice; and this time, while she was speaking, she began to know what else he would never remember, something so simple that she had missed it.

She stood there wan, almost ugly, really like some wretched pet monkey shivering in a cold climate. But she was going to have a child and - yes, looking at him, she was grownup, now, suddenly, as some people are said to turn white-haired overnight. (386)

The enemy within, as in "The Termitary" where insects gnaw at the white house, acts unbeknown to the inhabitants. Locked up inside their prejudices, white people are caught up in the turmoil of what they used to call "the situation," trying to control the lives of the overwhelming number of black people who, cheated out of their country, had to fight to get their rights of ownership back.

What is striking throughout Gordimer's writing is the discreet mastery of her style and the way she acts on her reader so as to involve him/her in the situations and conundrums she describes. A brief final look at some of her stylistic devices will be of import here. Not only showing how her characters may be displaced, disjointed and disrupted, Gordimer also manages to dislodge her reader from his/her comfortable seat by using various means of defamiliarization that trigger perplexity and suspension of belief. 


\section{Defamiliarizing the reader: a reading effect}

What is particularly striking, more and more so as book follows book, is Gordimer's way of suspending meaning by postponing the end of a sentence: to achieve this effect she resorts to the use of hyphens, commas and brackets. One instance of stretching/ fragmenting sentences thanks to a parenthesis marked by hyphens is the following: "His green eyes, at twenty eight, already were narrowed by the plump fold of the lower lid that marks joviality - whether cruelly shrewd or good natured - in middle age" ("Something Out There" 37).

The examples crop up often and in a puzzling way in Jump. They introduce some confusion for the reader, necessitating a retro-reading to understand the meaning of the sentences, the beginning of which has been lost or obscured. In "Spoils," the group of tourists enjoying a safari displays a sample of white South Africans thrown together on the expedition led by the black man Siza. At times, the atmosphere may become tense and, as suggested by the text, as acid as the grapes they are eating:

There are moments of acerbity; the grapes they are eating pop into sharp juice as they are bitten. One of the quiet guests has become communicative as will the kind who never risk ideas or opinions of their own but can reproduce, when a subject brings the opportunity, information they have read and stored. Bats; the twirling rags darker against the dark - someone suggested, as a woman cowered, that fear of them comes from the fact that they can't be heard approaching. (165)

The syntax is broken up by commas, semi-colons and hyphens, separating the verb "reproduce" from the complement "information," the noun "Bats" from the verb "suggested," and the pronoun locution "that fear of them," when this last bit is interrupted by "as a woman cowered."

For the reader, the fact that such sentences become more and more puzzling and abundant in the course of Gordimer's writing produces an effect of "double exposure," as in photography when two takes are superimposed. When parts of sentences are superimposed (here three elements are superimposed: bats, someone's speech, and the cowering woman), this produces a blurring effect, a perturbation leading to the slight displacement of the reader who is thus called upon to take in the ethics and aesthetics of the text. In the title story of Jump the word "destabilization" is used in the text to characterize the type of action undertaken by the young white counterrevolutionary: "from the word 'destabilization' with the image of some faulty piece of mechanism to be rocked from its base so that a sound structure may be put in its place" (13). Isn't this what Gordimer is also doing while destabilizing the canonical grammatical order by rocking its well-oiled "mechanism from its base," starting with the smooth flow of sentences? When the former political character in "Spoils" is speaking, his speech is mimicked using a number of commas, brackets and hyphens conveying the quick halting rhythm, providing information in asides as well as developing one strain of an idea:

Oh yes, we politicals were kept apart, but with time (I was there ten months) we managed to communicate. (There are so many ways you don't think of, outside, when you don't need to.)

One of them - young, my age - he was already declared a habitual criminal, inside for an indeterminate sentence. (167)

Another sentence in the same story describes the lions' dinner: 
The breathing mass, the beating hearts in the vehicle - watching the cubs jostling for places within the cadaver; the breathing mass, the beating hearts in the vehicle - being watched by the lionesses. The beasts have no time, it will be measured by their fill. (172)

This extraordinary sentence is based on the repetition of the same syntax portion devoid of verb, inducing a circling movement to it, a fact enhanced by the chiasmus ("watching/being watched"), and separated by two hyphens pointing at the action and designating what is to be seen. The animals are eating while the human beings stuck in the car are dehumanized, reduced to a mass of flesh, mere breathing bodies and beating hearts.

In an underhand, even covert, way, the narrator often undermines the focalizer's view and thought by resorting to ellipsis (silence), suggestion (the unsaid), free indirect discourse, and even a touch of allegory. Gordimer is a master of irony, a device involving a kind of double enunciation (or "exposure") where two meanings (overt and covert) are superimposed. These devices are instrumental in staging the return of a repressed and of a suggested subtext.

The narrator also manages, often ironically, to suggest discrepancies, contradictions, unknown to the character him/her self but perceptible to the reader. In "Six Feet of the Country" Graham Huggan spots a link or a kind of mirror image, between Lerice, the unnamed "farmer's" wife, and Petrus, the boy whose brother is lying dead in the hut.

She and Petrus both kept their eyes turned on me as I spoke, and, oddly, for those moments they looked exactly alike, though it sounds impossible: my wife, with her high, white forehead and her attenuated Englishwoman's body, and the poultry boy, with his bony bare feet below khaki trousers tied at the knee with string and the peculiar rankness of his nervous sweat coming from his skin. (79-80)

Both Lerice and Petrus turn away at the same time and leave the farmer alone. Huggan reads the passage as a denunciation of the patriarchal and racial values of the "farmer," following Martin Trump's remark that "Gordimer has perceived a common element in the degrading way in which black people and women are treated in her society" (Huggan 71).

Nadine Gordimer declared she kept writing what was necessary to her, what she felt to be urgent and sincere. Her books were repeatedly banned but she was spared the harsher treatment reserved for black writers. Her political stands are more or less (but often more) overtly stated and developed, often winning over the reader to the narrator's side when the latter is identifiable. They never overshadow the more intimate and complex developments: “I don't write about apartheid I write about people who happen to live under that system. I'm not a propagandist, I'm not a reporter, I'm a natural writer" "“Conversations" 27).

She wanted to make "something out there" significant and known to the world in her own way, which evolved over the years and became more and more outspoken and vibrant, sparing no side of her "beloved country" but seeing its most mysterious ways as well, the wonder of it all:

I began writing out of a sense of wonder about life, a sense of its mystery, and also out of a sense of its chaos. To me, all art is an attempt to make a private order out of the chaos in life, whether you're a painter or a musician or a writer. ("Conversations" 27) 
And sometimes, writers also turn out to be painters and musicians in their own splendid and useful way.

Liliane LOUVEL

University of Poitiers

\section{Works Cited}

BhabHa, Homi. The Location of Culture. London \& New York: Routledge, 1994.

Barnard, Rita. Apartheid and Beyond. Oxford: Oxford UP, 2006.

Freud, Sigmund. "L'inquiétante étrangeté." Essais de psychanalyse appliquée. Paris: Gallimard, coll. "Idées," 1976.

Gordimer, Nadine. "Is There Nowhere Else Where We Can Meet?" 1947. Face to Face. Johannesburg: Silver Leaf, 1949. 115-9.

—. The Conservationist. London: Penguin, 1974.

—. "Introduction." Selected Stories. London: Penguin, 1975. 9-14.

—. "Friday's Footprints." 1960. Selected Stories. Harmondsworth: Penguin, 1975. 125-43.

—."Livingstone's Companions." 1972. Selected Stories. Harmondsworth: Penguin, 1975. 293-320.

—. "Six Feet of the Country." 1956. Selected Stories. Harmondsworth: Penguin, 1975. 69-80.

—. "The Flash of Fireflies." 1968. Short Story Theories. Ed. Charles May. Athens, OH: Ohio UP, 1976. $178-81$.

—. "Letter to his Father." The New York Review of Books, Oct. 20, 1983.

—. "A Conversation with Nadine Gordimer." Salmagundi 62 (Winter 1984): 3-31.

—. "Something Out There." Salmagundi 62 (Winter 1984): 118-92.

—. "The Congo River." The Essential Gesture. London: Penguin, 1988. 157-85.

- - Jump and Other Stories. London: Bloomsbury, 1991.

HugGan, Graham. "Echoes from Elsewhere: Gordimer's Short Fiction as Social Critique." Research in African Literatures 25.1 (Spring 1994): 61-73. Web. 15 Aug. 2018.

PoE, Edgar Allan. "The Philosophy of Composition." Graham's Magazine 28.4 (April 1846): 163-7. $<$ https://www.eapoe.org/works/essays/philcomp.htm>. Web.

Woolf, Virginia. The Death of the Moth and Other Essays. 1942. Boston: Mariner, 1974.

—. Moments of Being. Ed. Jeanne Schulkind. New York \& London: Harvest, 1972.

- . "The Searchlight." The Complete Shorter Fiction. Ed. Susan Dick. New York \& London: Harvest, 1985. 263-6.

—. "The Lady in the Looking-Glass: A Reflection." The Complete Shorter Fiction. Ed. Susan Dick. New York \& London: Harvest, 1985. 215-9. 